\title{
UN ESCULTOR EN LA MÁLAGA DECIMONÓNICA: ANTONIO MARÍN SÁNCHEZ. APORTACIONES A SU VIDA Y CORPUS ARTÍSTICO
}

\section{A SCULPTOR IN THE DECIMONIC MÁLAGA: ANTONIO MARÍN SÁNCHEZ. CONTRIBUTIONS TO HIS LIFE AND ARTISTIC CORPUS}

\author{
Francisco Jesús Flores Matute \\ Universidad de Málaga. España \\ ORCID: 0000-002-1667-6481 \\ fjfloresmatute@hotmail.com
}

\begin{abstract}
En este artículo se intenta dar a conocer la figura del desconocido escultor Antonio Marín Sánchez, que vivió y trabajó en Málaga en el siglo XIX. Tras un intenso estudio de campo y una investigación profunda, se han conseguido abordar ciertos aspectos vitales de dicho escultor de los que no se tenía constancia por parte de la historiografía artística, así como la construcción de un catálogo de piezas firmadas y atribuibles a su mano que lo convierten, de improviso y dentro de su campo, en uno de los autores más relevantes en el panorama escultórico de la ciudad, casi al mismo nivel que la familia Gutiérrez de León, al caso, la saga de escultores más conocida y estudiada de este período histórico en la ciudad.
\end{abstract}

Palabras clave: Antonio Marín Sánchez; escultor; Málaga; siglo XIX; barroco.

This paper attempts to publicize the figure of the unknown sculptor Antonio Marín Sánchez, who lived and worked in the $19^{\text {th }}$ century in Málaga. After an intense field study and a deep investigation, it has been possible to address certain vital aspects of this sculptor of which there was no record by the artistic historiography, as well as the construction of a catalogue of signed and attributable pieces to his hand that make him, unexpectedly and within his professional field, one of the most relevant authors in the sculptural panorama of the city, almost at the same level as the Gutiérrez de León family, in this case, the saga of sculptors best known and studied of this historical period in the city.

Keywords: Antonio Marín Sánchez; sculptor; Málaga; $19^{\text {th }}$ century; Baroque. 


\section{VIDA DE ANTONIO MARÍN SÁNCHEZ}

Hasta el presente trabajo, poco conocíamos sobre la vida y obra del escultor malagueño del siglo XIX Antonio Marín Sánchez, más que algunas terracotas de estirpe costumbrista y que estaba emparentado, de algún modo, con la familia Marín, escultores en barro de Granada, cuyo miembro más importante y conocido fue Miguel Marín Torres ${ }^{1}$, autor de la estatua pública de Mariana Pineda de su ciudad, amén de otras tantas piezas de corte pintoresco, como el fantástico Majo sentado en actitud pensativa, acompañado de un perro, que se conserva en el Museo de la Casa de los Tiros de la ciudad de la Alhambra². Empero, la aparición de algunas obras de carácter sacro firmadas y fechadas por Antonio Marín nos ha permitido ampliar su catálogo en base a diversas atribuciones fundadas en las características formales y polícromas que comparten todas las obras que aquí se expondrán, dotadas de una serie de grafías muy características que forman parte de la poética del susodicho artista. Por otro lado, mucho de su vida lo hemos podido obtener gracias a los certificados de bautismo de su prole y los padrones, que nos han ofrecido jugosos datos que, hasta ahora, desconocíamos, tales como cuando se produjo su llegada a Málaga, quiénes fueron sus padres, sus profesiones, etc.

Así pues, Antonio Marín Sánchez nació en Granada en 1821 del matrimonio conformado por Antonio Félix Marín y María Juana Sánchez, siendo bautizado en la parroquial de San Cecilio y perteneciendo su familia, pues, al castizo barrio del Realejo. Desconocemos los motivos por los que se desplazó a Málaga hacia 1836, con tan solo 15 años de edad, aunque probablemente fuera en búsqueda de un porvenir que estuviera alejado del endogámico taller familiar, aprovechando las, a buen seguro, cualidades artísticas aprehendidas en su propia familia, teniendo en cuenta su futuro como escultor. En torno a 1839-1840 debió de contraer nupcias con Antonia Roca Díaz, cuyos padres fueron Francisco Roca, proveniente de Génova, y Catalina Díaz, gaditana, aunque dicho matrimonio llevaba cerca de medio siglo residiendo en Málaga, de donde fue natural su hija ${ }^{3}$.

La primera descendiente del matrimonio Marín Roca será Carolina Emilia, nacida en $1840^{4}$, a la cual le seguirán cinco hijos más, siendo bautizados todos ellos en la desaparecida parroquia de la Merced: María de los Dolores Emilia

\footnotetext{
${ }^{1}$ Gómez Román, 2008: 381.

2 Álvarez Cruz, 2005: 486-487.

3 Archivo Histórico Municipal de Málaga (AHMM), Padrón de 1854, distritos 1-4, f. 201.

${ }^{4}$ Por desgracia falleció con tan solo 3 años de edad de tabardillo. AHMM, Registro civil de muertos de la ciudad de Málaga de 1843, asiento $\mathrm{n}^{\circ} 1700$.
} 
Cesarea, nacida en 18435; Santiago de Santa Águeda, en 18456; Josefa Canuta, en 18487; Emilio Antonio Aniceto Juan Nepomuceno, en $1850^{8}$; y Concepción Epifanía, en $1853^{9}$. Por cierto, que este Emilio Antonio ${ }^{10}$ también será escultor y pintor, siendo premiado en el Fomento de las Artes de Madrid y habiendo presentado en la Exposición de Bellas Artes de dicha ciudad dos esculturas ${ }^{11}$, concretamente una copa en barro cocido de estilo pompeyano y una escultura en yeso representando a un pobre ${ }^{12}$. Se conserva también de este escultor una escultura costumbrista en el Museo Bellver de Sevilla.

Los primeros años de la familia se desarrollaron en la calle Victoria $n^{\circ} 15$, constando como profesión de Antonio Marín Sánchez la de muñequero -que es lo mismo que decir escultor de figuras de barro- y luego carabinero ${ }^{13}$. No obstante, con la llegada de su tercer hijo, Santiago, ya aparece en su certificado bautismal la profesión de escultor ${ }^{14}$, amén de que toda la familia se trasladó al $\mathrm{n}^{\mathrm{o}}$ 91 de la misma calle Victoria. Aquí viviría con sus suegros y una cuñada, tal y como consta en el padrón municipal de 1854, y tendría una nueva profesión oficial como tejero que, no obstante, podría redundar en su labor como muñequero, pues sabemos por el libro que escribió el inglés Henry David Inglis, Spain in 1830, que ya desde dicho año, "en los tejares del Ejido, cerca del convento de la Victoria" (de Málaga), podían adquirirse las figuras costumbristas ${ }^{15}$. A pesar de este baile de profesiones, tenemos constancia que nuestro artista se había matriculado en 1851 en la recién fundada Escuela de Bellas Artes de San Telmo, sin lugar a dudas con el objetivo de mejorar sus conocimientos y técnica artística $^{16}$. Es lógico pensar, no obstante, que su trabajo como escultor sería algo, en

5 AHMM, Registro civil de nacidos de la provincia de Málaga de 1843 (febrero-noviembre), asiento $\mathrm{n}^{\circ} 555$.

${ }^{6}$ AHMM, Registro civil de nacidos de la provincia de Málaga de 1844 (julio) a 1845 (marzo), asiento $\mathrm{n}^{\mathrm{o}} 354$.

7 AHMM, Registro civil de nacidos de la provincia de Málaga de 1847 (octubre) a 1848 (mayo), asiento ${ }^{\circ} 237$.

${ }^{8}$ AHMM, Registro civil de nacidos de la provincia de Málaga de 1850 (marzo-noviembre), asiento ${ }^{\circ} 1091$.

9 AHMM, Registro civil de nacidos de la provincia de Málaga de 1853 (marzo-octubre), asiento $\mathrm{n}^{\mathrm{o}} 1119$

${ }_{10}$ Más conocido por la historiografía como Antonio Marín Roca.

11 Cánovas Vallejo, 1908: 38.

12 Romero Torres, 1993: 42.

${ }_{13}$ Registros civiles de sus dos primeras hijas.

${ }_{14}$ También la de muñequero en el registro civil de su hija Josefa. No obstante, en el registro civil de su hijo Emilio Antonio (1850), aparece como jornalero.

15 Romero Torres, 1993: 52. Obsérvese también la cercanía que había entre su domicilio y dichos tejares.

${ }_{16}$ Romero Torres, 1993: 39. 
principio, secundario, a pesar de todo lo cual, y como veremos seguidamente, su faceta artística será la principal actividad profesional conocida a nivel público entre sus contemporáneos.

A mediados de 1859, Antonio Marín Sánchez y toda su familia realizarán un hecho trascendental en sus vidas que les afectará para el resto de las mismas. Y es que se convirtieron, en secreto, a la fe del cristianismo presbiteriano reformado. De hecho, Marín constituiría, junto a su dicha familia y otros tantos malagueños, la clandestina Iglesia Reformada de Málaga, convirtiéndose en uno de sus más destacados líderes ${ }^{17}$. Dicho ente eclesial se encargó de realizar proselitismo de su religión, amén de difundir numerosa literatura protestante, lo cual constituía un delito castigado por el Código Penal español del momento ${ }^{18}$. Y, en efecto, a través de una brecha de información entre el líder, activista protestante y cara visible de la disidencia religiosa en España, el granadino Manuel Matamoros García y uno de sus más cercanos seguidores, José Alhama, debido a la incautación de sus pertenencias y documentos, se pudo identificar a los principales líderes malagueños. La noche del 11 de abril de 1861 fueron detenidos por la policía Antonio Marín Sánchez, su mujer y su hijo mayor, junto a otros tantos miembros de la Iglesia Reformada malagueña que no pudieron escapar. Dos años de encierro tendrían que soportar, mientras que el resto de su familia quedaría en la indigencia $^{19}$. Tras el fallo judicial en 1862 contra el principal líder del reformismo en España, Matamoros, la justicia malagueña falló de igual modo en aplicar diversas penas a los principales dirigentes, tocándole a Marín nueve años de presidio ${ }^{20}$, que luego serían transformados en cinco años de trabajos forzados ${ }^{21}$. Posteriormente, se le conmutaría la pena por un tiempo igual al otorgado en el exilio, gracias a las presiones internacionales sobre el gobierno de Isabel II que pedían un trato más justo para con todos los disidentes protestantes andaluces, con Manuel Matamoros a la cabeza, juzgados por los tribunales españoles. Todos ellos saldrían, pues, en mayo de 1863 hacia el exilio ${ }^{22}$.

Marcelino Menéndez Pelayo, en su obra Historia de los heterodoxos españoles, nos relata que el escultor Marín ${ }^{23}$ y su familia fueron a parar a Burdeos

17 Vilar, 1994: 347.

18 "Delitos de apostasía pública y tentativas contra la Religión Católica", arts. 128, 130 y 136. Menéndez Pelayo, 1881: 685.

19 Vilar, 1994: 348-349.

${ }^{20}$ El Avisador Malagueño, 23-5-1863.

21 Vilar, 1994: 350.

22 Sierra Bernardino, 1998: 192.

${ }^{23}$ Así es como él lo denomina, lo cual nos indica que, efectivamente, a pesar de las profesiones no artísticas que, presuntamente, mantuvo durante su vida, realmente era conocido entre sus contemporáneos por su faceta como escultor. 
(Francia $)^{24}$. En efecto, en una carta que Manuel Matamoros escribió en 1864 a su amigo, el inglés William Greene, confirma que "Marín trabaja en Burdeos y está contento" 25 . ¿Y de qué trabajaba Marín en su nueva residencia en Burdeos? Pues, precisamente, de escultor. De hecho, tenemos localizados en una colección particular dos terracotas costumbristas, concretamente un Torero y un Majo con navaja, con sendas etiquetas en francés que dicen lo siguiente, según se ha podido conservar: "ANTONIO MARÍN DE MÁLAGA/ Fabricant de Statuettes... (roto)/ 233. R. Lagrange... (roto)". Ciertamente, existe dicha Rue (calle) en Bordeaux (Burdeos), la cual sería su residencia; pero es que, además, debemos prestar especial atención a la sintaxis: Antonio Marín “de” Málaga. Es decir, la etiqueta no nos indica que el producto, netamente castizo español, provenga de la capital de provincia andaluza, sino que es el propio autor el que proviene de Málaga y es la razón de ser de la temática de su obra pintoresca conservada en este caso, amén de que su procedencia constituye un elemento diferenciador y legitimador frente a otros autores que se dedicaran a la producción de esculturillas de barro.

La existencia de estos barros costumbristas fabricados por un artista malagueño fuera de su ámbito natural, es decir, en un país extranjero, nos indica dos cosas de suma importancia: por un lado, hasta qué punto este tipo de escultura castiza -también producida en Granada y Sevilla, aunque la fama fue de Málaga- era un producto amado y demandado por una clientela extranjera deseosa de adquirir piezas "orientalizantes" como esta para adorno de sus salas y gabinetes, como obra de carácter curioso y/o anecdótico, al punto de que un escultor especialista en este tipo de piezas temáticas, fuera de su contexto natural, pudiera vivir de la venta de este tipo de esculturas en un país extranjero. Por otro lado, nos señala la necesidad de revisar si todos los barros malagueños que hay repartidos por Europa, sobre todo en Reino Unido y Francia, pero también, por ejemplo, en Italia, provienen realmente de escultores asentados en Málaga y trabajando en dicha ciudad, tales como los Gutiérrez de León o los Cubero o, verdaderamente, unas pocas piezas, sobre todo las conservadas en Francia y zonas limítrofes, son realmente piezas salidas de la mano de Antonio Marín durante su etapa en Burdeos y serían, por tanto, un producto netamente extranjero, a pesar de ser fabricadas por un autor español y de que su temática fuera claramente andaluza.

Tras pasar los respectivos años de pena exiliado fuera de su país, Antonio Marín debió de regresar a Málaga -seguramente junto a su esposa, Antonia Roca, que le había acompañado en todas sus vicisitudes y penalidades y otros tantos hijos-, aprovechando la libertad de culto aceptada por la constitución de $1869^{26}$, ya que tenemos la certeza de una última imagen en Málaga que se encontraba

${ }^{24}$ Menéndez Pelayo, 1881: 686.

${ }^{25}$ García Rubio, 1994: 135.

${ }^{26}$ Moliner Prada,2016:https://journals.openedition.org/lerhistoria/2475?lang=es\#text (19-10-2019). 
firmada por él. La misma era la antigua Virgen del Amor, que fue titular de la hermandad de Jesús Nazareno "El Rico" durante el corto tiempo de poco más de un año, en 1935, pues pereció bajo las llamas iconoclastas de 1936. Esta imagen fue donación de don Miguel Ojeda Torrecilla a la hermandad en sustitución de la titular original de la corporación religiosa, que también fue destruida en las famosas quemas de iglesias y conventos de 1931 que sufrió la ciudad de Málaga. En su espalda se podía leer lo siguiente: "Layzo Antonio Marín. Septiembre 1873"27. La última información que tenemos al respecto de su vida es que se pasó a la fe anglicana -como muchos protestantes españoles de esta época, que se iniciaron en el presbiterianismo reformado (evangelismo), pero realmente seguían apegados a modos y creencias católicas, siendo lo más cercano la fe anglicana ${ }^{28}-$ y que fue feligrés de la catedral del Redentor en Madrid, sede de la Iglesia Española Reformada Episcopal, Comunión Anglicana, la cual fue fundada en 1880 por un amigo de nuestro escultor, también protestante español del momento: Juan Bautista Cabrera ${ }^{29}$. En esta ciudad, pues, creemos que viviría a partir de 1880 y moriría en la década de 1890. Quizás, es una posibilidad, también volviera a pasar sus últimos días en Burdeos junto a algún hijo que hubiera hecho su vida allí.

\section{CORPUS ARTÍSTICO DOCUMENTADO: TERRACOTAS Y ESCULTURA EN MADERA}

La producción barrista de nuestro escultor era conocida de antemano por la historiografía artística, a pesar de que se ha conservado menos cantidad de sus terracotas pintorescas con respecto a la de sus contemporáneos, tales como los Gutiérrez de León o los Cubero. Así, aparte de las dos terracotas comentadas (el Torero y el Majo con navaja), realizadas en Burdeos entre 1863 y 1868, podemos añadir también un Bandolero con guitarra (Figura 1), atribuible, por sus características, a la mano de este escultor. Todas estas esculturas son de correcta factura y proporción, aunque se muestran algo más hieráticas que las homónimas de las mismas temáticas de las otras sagas familiares de escultores comentados. Igualmente, los rostros se nos antojan más tendentes a la idealización que al retrato naturalista de los personajes representados. Es decir, a diferencia de las otras grandes familias de escultores barristas malagueños, que son partidarios de

${ }^{27}$ Archivo Histórico de la Hermandad de El Rico (AHHR), Escritura del acta notarial levantada a instancia de Miguel Ojeda y Manuel de la Cruz ante el notario Juan Marín Sells, Málaga, 21-4-1934.

${ }_{28}$ El tema del protestantismo decimonónico en España es harto complejo de entender y desarrollar, algo que no entra al caso en este estudio. Para más información al respecto, ver Vilar, 1994.

${ }_{29}$ Agradecemos la aportación de esta información al Rev. Carlos López Lozano, obispo de la Iglesia Española Reformada Episcopal, Comunión Anglicana. 
retratar con verosimilitud todo detalle realista y de representar posibles personas existentes de su ambiente, Marín, en estas esculturas en concreto, es tendente al mero estereotipo, que sin duda puede explicarse porque son obras realizadas, como hemos demostrado, en Burdeos, durante el exilio forzado de nuestro escultor y su familia, ya que no tendría contacto directo con los modelos reales en dicha situación y habría de tirar de memoria de lo que viera y realizara en sus años de estancia y formación malagueña. De estas tres, además, debemos destacar la figura del Torero, por su apostura clásica y elegante porte, que conforma una imagen naturalista que no satiriza su expresión, sino que, antes bien, la ennoblece.

Dentro de la producción de terracotas devocionales podemos añadir, por su parte, un barro que representa un Divino Pastor y que se expone en el Museo de Artes y Costumbres Populares de Málaga y un San Antonio de Padua inédito (Figura 2), que se venera en una pequeña hornacina del primer retablo situado en la zona del evangelio, según se entra, de la iglesia conventual de las Mercedarias de la Caridad de Málaga ${ }^{30}$. El mismo se basa en la pintura de Murillo que realizó para el convento capuchino de Sevilla y que actualmente se expone en el Museo de Bellas Artes de dicha ciudad. En la base de la peana, a palillo, se puede leer lo siguiente: "S. Antonio de Padua. Pintr. de Murillo. Marín". A diferencia de los barros pintoresquistas, que señalan su autoría mediante una etiqueta de papel pegada a la base de lo mismos, en los casos religiosos Marín firma a palillo con su nombre abreviado -caso del primer ejemplo- o con, simplemente, su primer apellido -caso del segundo, como hemos visto-. Así lo hará, también, en las obras religiosas de mayor tamaño que veremos seguidamente. En todas ellas se nos asegura una misma mano por la característica y particular grafía, lo cual, junto a las fechas que presentan las esculturas sacras en madera a analizar posteriormente, nos afirma con rotundidad la autoría de todas estas esculturas por parte de Marín Sánchez y no de su hijo, Antonio Marín Roca -que también fue escultor como señalamos anteriormente-, como podría llegar a pensarse porque, empero, por las fechas que presentan las susodichas esculturas en madera sería imposible que las realizara el segundo, ya que tendría tan solo 9 años de edad -recordamos que localizamos la fecha de nacimiento de Marín Roca, producido en 1850, mientras que las esculturas en madera se encuentran firmadas en 1859-. Teniendo, pues, todas estas esculturas la misma grafía y descartándose por edad al hijo, es obvio señalar la autoría

${ }^{30}$ En esta iglesia de las Mercedarias hay dos barros más, concretamente un San Rafael, en una hornacina del retablo donde se venera una imagen de la Inmaculada, y una Beata Mariana de Jesús, en una hornacina dentro del retablo donde se encuentra una Virgen de las Angustias serializada de finales del siglo XIX o principios del XX. Por sus características formales y polícromas, no obstante, estas piezas las vinculamos con Antonio Gutiérrez de León. 
definitiva en Marín Sánchez, algo que ya fue hecho, además, por el historiador del arte Romero Torres en el referenciado Divino Pastor ${ }^{31}$.

Esta última terracota, que, como en el caso del San Antonio, pareciera que pudo ser inspirada por la pintura del mismo título de Murillo expuesta en el $\mathrm{Mu}$ seo del Prado con desigual fortuna, debe considerarse su ejemplar conservado y documentado más antiguo, pues podemos observar los intentos de Marín por realizar una obra bien terminada pero que, sin embargo, no termina de transmitir seguridad y/o conocimiento de proporciones y volúmenes como sí lo harán, en distinto grado, sus esculturas en madera o las terracotas ya vistas, destacando, en igualdad de filiación temática, la del San Antonio. Resulta evidente, pues, que dicha pieza debiera realizarla nuestro escultor antes de su formación en la Escuela de Bellas Artes de San Telmo, donde adquiriría una buena base artística que le permitiera acometer empresas más complejas como la talla de esculturas en madera y obras, en general, con mejor terminación y calidad artística.

En el caso de la esculturilla de San Antonio de Padua podemos apreciar una mejor calidad, proporción y terminación, amén de una serie de estilemas morfológicos en los rostros del santo y el Niño Jesús muy característicos que se repetirán en las siguientes esculturas que veremos y que se resumen en la forma de realizar los ojos, la boca y la presencia de unos marcados huesos cigomáticos. Sin duda, esta pieza debió ser realizada tras el paso del escultor por la Escuela de Bellas Artes de San Telmo.

En cuanto a su escultura en madera sacra, no había conocimiento alguno hasta el descubrimiento, por nuestra parte, de una pareja de esculturas talladas en madera -un San José y una Virgen-, que se encuentran firmadas por la espalda con la siguiente leyenda: "Antonio Marín. Málaga. Año de 1859" y que miden entre los 85 y $87 \mathrm{~cm}$ (Figura 3). La escultura de la Virgen se encuentra repintada groseramente con pintura plástica al punto de hacer irreconocibles sus rasgos primigenios hasta que una restauración se los devuelva en la medida en que sea posible; empero, el San José se conserva íntegro en su estado original, tanto de talla como de policromía.

Estas esculturas, como era habitual también en las obras sacras de otras sagas familiares de escultores malagueños en el siglo XIX, tales como los Gutiérrez de León o los Gutiérrez Muñiz-Toro-Jimena, beben de modelos impuestos por el escultor barroco granadino Pedro de Mena y por el dieciochesco malagueño Fernando Ortiz que, por otra parte, era realmente tenido en la época como Pedro de Mena. Es decir, en el siglo XIX, la producción del segundo era confundida con la del famoso escultor granadino del Barroco y así, aunque inconscientemente los escultores decimonónicos malagueños realizaban un revival de los modelos de Ortiz, sobre todo en los rostros de sus dolorosas, en su

\footnotetext{
${ }^{31}$ Romero Torres, 1993: 39.
} 
imaginario, que era el de todos sus contemporáneos, estaban realizando una relectura de las esculturas de Mena $^{32}$.

Los rostros de estas dos esculturas se construyen mediante un óvalo facial de dibujo limpio y algo ovoide, donde los rasgos más destacables son los que conforman la construcción de la boca, los pómulos y los ojos. La boca se presenta prácticamente cerrada, permitiendo, no obstante, la visión de la dentadura superior. El labio superior muestra una marcada forma de "M", debido al detallismo a la hora de tallar los pliegues del mismo. La conjunción entre la boca y unos manifiestos pliegues nasolabiales otorgan a los rostros una expresividad que denotan cierto mohín e hieratismo. El filtrum -el pliegue central entre el labio superior y la nariz- se presenta, asimismo, profundo. Por su parte, los pómulos se encuentran siempre muy destacados, con los huesos cigomáticos evidenciados. La nariz es algo gruesa y rectilínea y los ojos, rasgados, tienen forma de cuña invertida, con el párpado inferior recto y el superior curvo. Las cejas son finas y se encuentran delineadas a pincel, conformando un característico arco. Terminan de configurar el busto un cuello algo robusto, con esbozos de anatomización, unas frentes amplias y un cuero cabelludo peinado con raya central, con guedejas de pelo de escaso volumen que caen de forma lacia, como si estuvieran mojadas, y pegadas al perímetro craneal. Los mechones se dibujan muy finamente, de forma preciosista y mediante rayas paralelas muy simétricas, al gusto neoclásico. Por su parte, las policromías son nacaradas, de tonos limpios y algo fríos, presentando frescores a base de suaves veladuras siempre sobre los pómulos, así como punta de la nariz, mentón y párpados superiores. También presentan policromados, con un pincel fino, pequeños mechones de pelo a lo largo de donde se une cabellera con piel, otorgando más realismo a las imágenes de esta forma.

Por otra parte, las manos en ambos simulacros, tanto la Virgen como el San José, son correctas, aunque algo esquemáticas, con la característica forma de tenedor. Sin embargo, sí se encuentran detalladas, con dedos finos y uñas, articulaciones y pliegues bien definidos, así como las venas subcutáneas, en el caso de las manos del San José. La encarnadura, por último, se encarga de mejorar dichos detalles.

La última obra firmada y fechada en 1873 por nuestro escultor era la ya referenciada, en el apartado biográfico, Virgen del Amor, dolorosa de tamaño natural destruida en 1936, pero de la que ha quedado una buena documentación gráfica que nos ha permitido conocerla y estudiarla con detenimiento. Como en las otras esculturas firmadas por Marín, apreciamos una serie de rasgos que se repiten, sobre todo en lo que es la zona nasolabial (boca, filtrum, nariz) pero también en la forma de construir el óvalo facial o marcar los pómulos. Lógicamente, el tipo iconográfico demanda una diferenciación a la hora de tallar la zona ocular para

${ }^{32}$ Sánchez López, 1996: 292. 
expresar el dolor que, en este caso en particular, es dulcificado. Y es que, como en otras dolorosas de la época realizadas por autores malagueños, la evidente inspiración en la obra de Mena y Ortiz -y en este caso en particular, más en el del primero- es tamizada a favor de una belleza externa. Sus manos, de nuevo y como en los casos anteriores, se muestran algo esquemáticas y artificiosas aunque, empero, bien realizadas y terminadas, con una correcta proporción.

Por sus enormes similitudes formales con esta Virgen del Amor y las otras esculturas firmadas de Marín, creemos atribuible a su mano a la Virgen de los Dolores y Esperanza, titular de la hermandad de Humildad y Paciencia de Málaga, que puede haber sido realizada en la década de 1870, como la dolorosa de la hermandad del Rico (Figura 4). La forma de tallar la boca, filtrum, cuello, cabello y ojos, así como los pliegues nasolabiales se corresponde con las piezas ya vistas de nuestro escultor. Además, también presenta el característico frontalismo de sus rasgos fisonómicos. Empero, la nariz ha sido un poco retallada, aplanándola y restándole volumen tanto a la punta como a la protuberancia del hueso nasal y el entrecejo ha sido algo remarcado, al igual que la zona de los arcos supraorbitales, para acentuar el patetismo. Todo ello ha conseguido embrutecer parcialmente el rostro de la imagen aunque, no obstante, podría tratarse de una de sus más felices creaciones, por cuanto se hace evidente el intento del escultor por adherirse a los postulados clasicistas, llevando a cabo una dolorosa a caballo entre la corrección del academicismo, que valora más la técnica y la pulcritud de líneas, y el sentimentalismo y expresividad del barroco.

\section{OBRAS ATRIBUIBLES: EL CASO DE LA VIRGEN DE LOS REMEDIOS DE MÁLAGA}

Existe otra serie de imágenes atribuibles a la mano de Antonio Marín a nuestro parecer, de entre las cuales, la más destacable sería la Virgen de los Remedios, de la parroquia de los Santos Mártires de Málaga, que ya fuera atribuida, no obstante, aunque igualmente discutida ${ }^{33}$, al escultor dieciochesco Fernando Ortiz por parte del profesor Romero Torres, en base a la similitud de dicha imagen con otras tantas de dicho autor, amén de apoyarse en una serie de datos documentales históricos para avalar dicha atribución. Empero, por nuestra parte podemos aportar nuevos documentos históricos que explicarían que dicha imagen no fuera realizada en el siglo XVIII, sino en el XIX, que, junto a los rasgos fisonómicos de la susodicha -tremendamente parecidos a las esculturas firmadas por Marín como el San José y que explican anomalías ya señaladas por el propio Romero Torres tales como la forma de los ojos, entre otras, que no acababan de encajar en la producción de Ortiz y sí en el modo de hacerlo de Marín-, terminarían de

${ }^{33}$ Sánchez López, 2007: 83-84. 
inclinar la balanza atributiva de dicha imagen -y tantas otras enormemente parecidas entre sí- hacia Antonio Marín Sánchez. Si no, al menos, a demostrar la filiación decimonónica de la susodicha escultura. Pero empecemos desde el principio para contextualizar debidamente nuestra atribución de tan icónica imagen mariana malagueña y entender la discusión que se construye en torno a la misma por parte de la historiografía artística:

Comenzando por los datos históricos de la hermandad que tiene por titular a dicha Virgen de los Remedios, es de señalar, primeramente, la dependencia casi absoluta que la misma tenía al patronazgo que sobre la escultura y su capilla ejerció la familia Bastardo de Cisneros. La primitiva titular debió ser de filiación tardogótica o protorrenacentista, tal y como numerosos documentos señalan, al comparar a dicha escultura con la Virgen de la Victoria, patrona de Málaga. Es más, la familia Bastardo de Cisneros señala continuamente en diversos documentos que dicha imagen fue un regalo de los Reyes Católicos a su ascendiente, el capitán Hernán González Bastardo de Escandón ${ }^{34}$. El 15 de agosto de 1735, el corregidor de Córdoba, Francisco Bastardo de Cisneros y Mondragón, inaugurará una remozada capilla familiar y una supuesta nueva imagen de la Virgen de los Remedios que no fue tal, sino una simple renovación estética, al gusto de la época, de la titular tardogótica ${ }^{35}$. Esta es la primera fecha señalada por Romero Torres para justificar la filiación dieciochesca de la actual escultura ${ }^{36}$, aunque luego se retractará de la misma, afirmando que podría haber sido realizada en las décadas de 1750 y $1760^{37}$, justificando la posible hechura en dichos años de la actual imagen de vestir, y, entre otras cosas, en el auge e importancia adquirido por la congregación que daba culto a dicho simulacro, a raíz del protectorado de la Virgen sobre su parroquia como consecuencia del terremoto de Lisboa el 1 de noviembre de 1755 y sus efectos posteriores, como el tsunami que se produjo el día 27 del mismo mes. La cuestión es que se sigue señalando en documentos posteriores a 1735, como la Novena Sacratísima de $1754^{38}$ o, sobre todo, el testamento de 1820 de Francisco María Bastardo de Cisneros y Melgarejo ${ }^{39}$, que la imagen que se seguía venerando en la capilla, propiedad, como la escultura, del mayorazgo de los Bastardo de Cisneros, era la que fuera regalada a su antepasado por los Reyes Católicos, por tanto de filiación tardogótica y no barroca como

${ }^{34}$ Reder Gadow, 2007: 52-53.

${ }^{35}$ Sánchez López, 2007: 75-77. Seguramente se tratase de un estofado de las vestiduras y nueva encarnadura.

${ }^{36}$ Romero Torres, 2007: 87-89.

${ }^{37}$ Romero Torres, 2017: 226.

${ }^{38}$ Archivo Díaz de Escovar (ADE), caja 135, Novena sacratísima a la Gloria de la misma Gloria..., Málaga, Imprenta de la dignidad episcopal de la Santa Yglesia Catedral, en la Plaza, 1754, pp. 36-40.

${ }^{39}$ Archivo Histórico Provincial de Málaga (AHPM), leg. 3703, ff. 548r-552v. 
la actual. Podría justificarse la hechura de una nueva imagen barroca que sustituyera a la titular gótica en la segunda mitad del siglo XVIII debido al referido auge que podría haber disfrutado la hermandad de los Remedios fusionada con la del Rosario ${ }^{40}$, amén de las documentadas salidas rezando el rosario y haciendo la Vía Sacra todos los años el 1 de noviembre ${ }^{41}$. Empero, hoy se encuentra muy documentado y estudiado el fenómeno rosariano de dicho siglo, sabiéndose que prácticamente todas las hermandades del rosario existentes en Andalucía en esa época lo que sacaban en procesión no era ninguna escultura, sino un simpecado/ estandarte que contenía una imagen, generalmente pintada de su titular, que se quedaba todo el año en su respectivo altar y recibía culto interno ${ }^{42}$. No tendría ningún sentido, pues, la existencia de tres imágenes veneradas por la misma hermandad y con la misma advocación a la vez, a saber: la titular primigenia tardogótica, el simpecado - que era lo que salía a la calle-y la supuesta nueva escultura de vestir -identificada como la actual-, que carecería de razón si la función de la hermandad rosariana era rezar el rosario públicamente presidido por su simpecado $^{43}$, y los cultos internos -tales como la función votiva recordatoria de la protección de la Virgen de los Remedios ante el llamado "Temblor del Agua" del 27 de noviembre de 1755-, debieran ser presididos por su titular de toda la vida, la imagen tardogótica.

Un último dato histórico justificaría que la actual imagen de vestir de la Virgen de los Remedios fuera realizada en el siglo XIX y no en el XVIII, y este tendrá lugar cuando en 1840 se produzca un hecho traumático en la familia de los Bastardo de Cisneros y que afectaría a la congregación del Santo Rosario de Nuestra

${ }^{40}$ Archivo Catedral de Málaga (ACM), Justificación de las rentas y bienes eclesiásticos contribuyentes a las Reales Gracias de los Subsidios de Málaga, Alhaurín de la Torre, Churriana y Torremolinos, 1795, leg. 215, pza. 6, ff. 20r-21v.

${ }^{41}$ ADE, caja 135, Iglesia de los Mártires, asunto: Hermandad de los Remedios. Notas manuscritas.

${ }^{42}$ Para mejor y más completa información al respecto de dicho fenómeno devocional, véase Romero Mensaque, 2010, y el blog del investigador Jurado Vela "El Rosario en Málaga”.

43 Jurado Vela, 2017: https://rosarioenmalaga.com/2017/07/17/geografia-rosarianamalacitana-tercera-parte/. Muy esclarecedor es también, al caso de este estudio, cómo Romero Mensaque señala que la principal procesión de las hermandades rosarianas, el conocido como Rosario de Gala, fue "muy pujante durante el siglo XVIII y primera mitad del XIX, produciéndose su declive en la segunda mitad del XIX, donde se prefiere sustituir la insignia principal, el simpecado, por la propia imagen titular". Romero Mensaque, 2010: 640. Este es un dato que perfectamente también podría explicar la realización de la actual escultura de vestir de la Virgen de los Remedios: ante la desaparición del icono tardogótico original y la preferencia de la congregación por realizar su procesión con una escultura en vez del simpecado, como habría sido lo habitual en el pasado, habría encargado la nueva imagen, ya al gusto de la época. 
Señora de los Remedios, al desaparecer el mayorazgo de la rama malagueña de dicha familia, pues el anteriormente mencionado Francisco María y su mujer, Petronila Ortega Rengel, morirán sin descendencia, por lo que las distintas ramas de la familia pleitearán para repartirse la herencia de dicho mayorazgo ${ }^{44}$, entre las que se incluían, presumiblemente, la capilla, los enseres de esta y la imagen de la Virgen de los Remedios ${ }^{45}$. La hermandad se encontraría, pues, sin su histórica imagen titular, la tardogótica, y tendría la necesidad de encargar una nueva escultura, ya sí, acorde a los gustos de la época, es decir, que fuera de filiación estética plenamente barroca. También sabemos que la capilla que fuera de la hermandad del Santo Rosario de los Santos Mártires -que, recordemos, llegaría a fusionarse con la congregación de los Remedios-, la cual era la cuarta contando desde los pies del templo por la nave de la epístola ${ }^{46}$, fue ocupada desde 1835 por la imagen del Santo Cristo de la Salud, patrón de la ciudad, y desde 1849 por la hermandad del Huerto ${ }^{47}$ tras la marcha del patrón a su actual iglesia en calle Compañía. ¿Qué podría explicarnos esto? Que, efectivamente, la hermandad rosariana de los Remedios se había quedado sin la capilla original por el repartimiento del mayorazgo de los Bastardo y también sin su imagen, que podría haber pasado a ser venerada en la capilla de la hermandad del Rosario si no supiéramos que no fue así debido a que esta fue ocupada indistintamente por otras importantes imágenes y hermandades. La actual imagen de la Virgen de los Remedios, pues, se habría realizado en un momento indeterminado de la segunda mitad del siglo XIX, en una posible reactivación cultual de su hermandad y ante la falta del simulacro devocional primigenio.

En cuanto a las cuestiones formales de la propia escultura de vestir de la Virgen de los Remedios y su vinculación, por nuestra parte, con la mano de Antonio Marín Sánchez la explicamos no solo por la enorme similitud existente entre ambos rostros, sino también por una parecida calidad artística que, sin ser despreciable, consideramos que es correcta, pero no excepcionalmente extraordinaria, como cabría esperarse de las esculturas firmadas por Ortiz, a nuestro parecer superiores, no solo y lógicamente a las esculturas firmadas por Marín, ya vistas,

${ }^{44}$ Datos aportados por el investigador Juan Cristóbal Jurado Vela, y que serán convenientemente desarrollados y referenciados en una futura publicación que el mismo está preparando. Desde aquí, le agradecemos enormemente su generosidad al compartir su trabajo investigador para terminar de entender el por qué del posible cambio de la imagen de la Virgen de los Remedios.

${ }^{45}$ Esta talla se ha llegado a relacionar con la imagen tardogótica de la misma advocación que se venera en la actualidad en la catedral malagueña. Si así fuera, la llegada de la misma habría podido venir del hermano de Francisco María Bastardo, de nombre José, que era en estos momentos racionero de la catedral.

46 Jurado Vela, 2017: https://rosarioenmalaga.com/2017/07/17/geografia-rosarianamalacitana-tercera-parte/

${ }^{47}$ El Avisador Malagueño, Málaga, 16-4-1849. 
sino también a la propia escultura de la Virgen de los Remedios. Además, esta imagen mariana presenta una serie de irregularidades formales, ya señaladas por el propio Romero Torres, que no coinciden plenamente con la producción del maestro dieciochesco malagueño. A saber: los ojos, cuya forma en cuña invertida los justifica Romero Torres como un posible retalle de los mismos, ya que "no debió tenerlos tan abiertos" en origen ${ }^{48}$ y la propia escultura del Niño Jesús, que no termina de encajar en la producción de $\mathrm{Ortiz}^{49}$, aun cuando ciertamente es deudora de su estilo, aunque de forma más parca. Los ojos de la Virgen, como podemos observar y comparar, sí coinciden plenamente con cómo los presenta tallados la académica imagen de San José, y, con ello, el resto de rasgos icónicos que no terminamos de apreciar completamente en las imágenes de Ortiz, tales como la boca -con un labio superior marcado, lo cual otorga una expresión de mohín a ambas imágenes; expresión que no encontramos en las esculturas "gloriosas" o hagiográficas de Ortiz y sí en las documentadas de Marín, así como en las que se le atribuyen, como veremos-, o los marcados pómulos, debido al desplazamiento hacia delante de los huesos cigomáticos (Figura 5). En cuanto al Niño, apreciamos mucho más plausible su morfología y talla debido a una influencia estética de la familia Gutiérrez de León que, recordemos, fueron maestros de Marín Sánchez. El cráneo, forma de tallar el pelo y el concepto de esta escultura se asemejan mucho más a, por ejemplo, los querubines tallados por Salvador Gutiérrez de León presentes a los pies del grupo de San Juan de Sahagún realizado por dicho escultor para el trascoro de la catedral de Málaga. Además, también tenemos a la Virgen del Rosario de Serrato, muy parecida a la Virgen de los Remedios malagueña y al San José de Marín (Figura 5) cuyo Niño Jesús, precisamente, se muestra también extremadamente parecido al Niño Jesús que presenta el pequeño barro de San Antonio de Padua, firmado por nuestro escultor decimonónico (Figura 6). Cerraríamos, de esta manera, el círculo que justificaría, no solo documentalmente, sino también formalmente por la presencia de otras piezas firmadas de Marín, la atribución, por nuestra parte, de ambas esculturas marianas: la de los Remedios y la del Rosario de Serrato. Y es que creemos lógico pensar que, si al caso el Niño Jesús de la primera imagen mariana fuera un añadido posterior $-\mathrm{y}$, por tanto, no de Ortiz-, ¿cómo justificar la extraordinaria coincidencia del Niño Jesús de la segunda imagen mariana con un niño firmado por Marín y, a la vez, que ambos simulacros devocionales coincidan más plenamente a nivel formal y morfológico con el San José de este escultor del XIX que con las obras firmadas por Ortiz?

Pero es que, además, encontramos más imágenes tremendamente parecidas entre sí y con el susodicho San José que, a su vez, claramente son esculturas correctas pero no llegan, en absoluto, a tener la calidad artística de las obras de Fernando Ortiz, aunque bien es cierto señalar que, de algún modo, estéticamente

\footnotetext{
${ }^{48}$ Romero Torres, 2017: 223.

49 Romero Torres, 2007: 89.
} 
beben de los modos propuestos por el escultor dieciochesco. Esto último, empero, es algo muy habitual, como ya señaláramos anteriormente, dentro de los escultores decimonónicos malagueños, escapándose algo más de dicha filiación estética las obras producidas por los Gutiérrez de León, sobre todo por Rafael y su hijo Antonio, debido a la introducción del academicismo en sus piezas sacras, a diferencia de otros autores como Antonio Marín o la familia Gutiérrez Muñiz-ToroJimena $^{50}$, que realizan obras sacras claramente retardatarias para con lo que su época artísticamente demandaba, pero que eran muy del gusto de su clientela, generalmente la burguesía, por encima del estamento eclesiástico, que había dado un paso atrás en el mecenazgo religioso con respecto a siglos anteriores.

Así, tenemos las esculturas de Santa Escolástica, venerada en el lado del evangelio del presbiterio de la ermita de San Benito de Campillos (Málaga) y una Inmaculada Concepción de talla completa (Figura 5), que se encuentra en la primera capilla, según se entra, de la nave de la epístola de la iglesia conventual de las Mercedarias de la Caridad de Málaga - un templo, convento y orden, por cierto, fundados a finales del siglo XIX, por lo que no cabría esperarse que dicha escultura proviniera de otra fundación o convento que justificara su posible mayor antigüedad con respecto a la datación que le proponemos dentro del siglo XIX, ya sea por su propio contexto, ya sea por su filiación a Marín debido a sus rasgos morfológicos-. De la primera poco más podemos decir que no se haya dicho ya, pues sus características morfológicas son las mismas que las de anteriores esculturas ya vistas, firmadas o atribuibles por nuestra parte.

De la Inmaculada, que por su extremado parecido a nivel fisonómico con la Virgen de los Remedios, incluso misma resolución de la caída de sus cabellos, podríamos considerarla otra obra de Ortiz ateniéndonos a la ya comentada atribución de Romero Torres, habríamos de descartar dicha filiación de autoría ateniéndonos a la mayor información que toda la escultura, por ser de talla completa y bulto redondo, nos ofrece con respecto a la segunda imagen mariana, de vestir y de la que solamente se conserva la cabeza y el Niño Jesús. Es decir, esta escultura, por todas sus características y el propio contexto en el que se venera, habría de añadir un argumento más en contra de la atribución hacia Ortiz por parte del historiador del arte malagueño y favorecería, a nuestro parecer, nuestra atribución hacia Marín Sánchez. Y es que la talla de sus vestiduras, aunque pudiera considerarse una obra de la primera etapa de Ortiz, no termina de alcanzar la maestría que ya se preconiza en otras esculturas completamente talladas por el maestro malagueño en dicha primera etapa, como su San Francisco de Asís,

${ }^{50}$ De esta familia de escultores malagueños de tránsito del siglo XVIII al XIX saldrá un estudio próximamente, realizado por nosotros, con nuevas e inéditas obras documentadas y conservadas, que nos ha permitido comprobar, como en el caso de Marín, la enorme deuda estética que tienen sus imágenes sobre los modelos de Pedro de Mena y, sobre todo, Fernando Ortiz. 
fechado en 1738 y que se encuentra en el Museo Nacional de Escultura de Valladolid o las destruidas Virgen de la Soledad de San Pablo y la Magdalena arrodillada de la iglesia conventual de Santo Domingo, ambas en Málaga. En efecto, la talla de la Inmaculada mercedaria presenta un golpe de gubia muy epidérmico, sobre todo en su túnica, a diferencia de las tallas de las referenciadas primeras obras de Ortiz, mucho más valientes, profundas y dinámicas, de abundantes pliegues verticales que generan una vibración en la contemplación de la túnica (Figura 7). La talla de la Inmaculada, como en tantas obras vistas de Marín, es correcta y proporcionada, pero no llega al nivel de los maestros del pasado o, ni siquiera, al nivel mostrado por sus contemporáneos, como los Gutiérrez de León. Su policromía, sobre todo sus estofados, tampoco coinciden, en absoluto, con los presentes en las obras firmadas de Ortiz, ni los motivos florales de gusto rococó y sus correspondientes rocallas en "c" que le son tan propios, siendo los motivos decorativos de esta escultura de raigambre isabelina. Tampoco se aprecia que la escultura se encuentre repintada, sino que, todo lo contrario, la policromía que posee es la original/primigenia ${ }^{51}$. Por otro lado, las cabezas de querubines presentes en la nube sobre la que se sustenta la imagen de la Virgen se muestran, como cabría de esperar, muy parecidos fisonómicamente al Niño Jesús de la Virgen de los Remedios y al Niño Jesús del San Antonio de Padua firmado por Marín, que, no obstante, al ser una pieza de solo unos pocos centímetros de altura, se nos presenta algo menos detallado. Empero, fijémonos cómo este último y los querubines coinciden también a nivel polícromo con la misma forma de pintar los ojos y cejas, amén de su encarnadura en general (Figura 8).

Por lo demás, a nivel formal, es una escultura completamente deudora de los modelos del mismo tipo iconográfico tallados por Pedro de Mena a partir de $1674^{52}$. Quizás Marín conociera este tipo de modelo a través de la imagen de Mena que se conservaba en el convento del Ángel Custodio de Málaga ${ }^{53}$.

Finalmente, comentar que existen más obras atribuibles a Marín, muy generalmente en colecciones particulares, pero por mor de la extensión de este artículo se hace inviable sacarlas a la luz. Empero, es de destacar la variabilidad de temas sacros ofrecidos por este autor con los ejemplos ya mostrados, lo cual demuestra que era un escultor versátil y requerido por una clientela variopinta, aunque generalmente burguesa, como era la norma en su época y contexto. Y todo ello a pesar de haber llegado a ser invisibilizado, seguramente de forma deliberada por su condición de cristiano protestante, por la historiografía de su época, caso

${ }^{51}$ Desde aquí mi agradecimiento a las hermanas mercedarias de la Caridad por permitirme acceder de forma cercana a la escultura.

${ }_{52}$ Romero Torres, 2019: 180.

${ }^{53}$ Romero Torres, 2019: 186. 
del malagueño Guillén Robles en su Historia de Málaga y su provincia, siendo el único escultor de la ciudad al que ni siquiera nombra de pasada ${ }^{54}$.

\section{CONCLUSIÓN}

Como hemos podido comprobar en este trabajo de investigación, la obra del escultor Antonio Marín Sánchez es acorde a las vicisitudes de su vida, por cuanto la estética eminentemente tardobarroca e, incluso, arcaizante que denota la susodicha no es más que el reflejo de una vida al servicio de una clientela burguesa muy apegada al pasado barroco de la ciudad, con sus dos referentes escultóricos a la cabeza: Pedro de Mena y Fernando Ortiz. A diferencia de sus contemporáneos, tales como Rafael y, sobre todo, Antonio Gutiérrez de León -que formaban parte del mundo académico y con una clientela presumiblemente más prestigiosa, que les permitió, entre otras cosas, dedicarse plenamente a la escultura, intentando transmitir el ideal neoclásico y academicista en sus obras, cosa que lograron más en su obra profana que en la religiosa, tendente al eclecticismo con tal de satisfacer los consabidos gustos anticuados de su clientela burguesa en dicho campo-, Antonio Marín ejerció su profesión de escultor como forma casi de subsistencia, relegándola a un segundo plano, como hemos visto. Añadido esto a su peripecia vital como cristiano protestante, lo que le acarreó, junto a su familia, cárcel y exilio durante un determinado tiempo, nos da como resultado su incapacidad para florecer como escultor plenamente académico que pudiera realizar o recibir encargos de obras civiles de cierta envergadura o de parte de las grandes instituciones y personalidades de la ciudad. Su corpus artístico es reflejo, pues, de la demanda comercial de su tiempo: por un lado, los barros costumbristas, muy populares sobre todo para los extranjeros y personificaciones de la visión romántica castiza que se tenía de España y de Andalucía en concreto. Por otro, su producción religiosa, relegada a servir de adorno sacro de las estancias burguesas o de ser titular de las hermandades, cuyos gustos eran claramente barrocos y no toleraban ni querían piezas personales propias de su tiempo -es decir, obras académicas-, sino que seguían encargando obras que imitaran, en la medida de sus posibilidades, las obras de los maestros del pasado. Además de todo esto, la aparición de un corpus sacro medianamente extenso y adjudicable a su mano, a pesar de lo aparentemente secundaria que era su carrera como escultor, nos muestra cómo, no solo sabía satisfacer el gusto anticuado de su clientela, sino que sería un autor realmente económico frente a otros escultores de mucho más prestigio, tanto social, como académico - es decir, la familia Gutiérrez de León ${ }^{55}$, la de los

${ }^{54}$ Guillén Robles, 1874: 663-664.

${ }^{55}$ Los cuales eran, efectivamente, los escultores mejor cotizados de todos, siendo los precios de sus piezas, a decir de varios extranjeros que adquirieron sus productos, los más altos de todo el panorama artístico en la ciudad. Romero Torres, 1993: 29. 
Cubero o la Gutiérrez Muñiz-Toro, entre tantos otros- y que, obviamente, sería ayudado en su labor por sus hijos -recordemos que sabemos que su hijo Emilio Antonio se dedicará también a la escultura-. En definitiva, su obra estaba encaminada no tanto en crear arte de primer nivel, sino piezas que satisficieran un determinado nicho de mercado con tal de que le ayudaran a vivir dignamente junto a su familia, para lo cual ejercitaría otras profesiones. Todo esto explica las carencias y virtudes de su obra artística: la misma no es más que un producto auténtico de su tiempo en una ciudad, Málaga, que aún estaba por vivir más cambios sociales en futuros venideros.

Fecha de recepción: 18 de octubre de 2019

Fecha de aceptación: 13 de abril de 2020

\section{BIBLIOGRAFÍA}

Álvarez Cruz, Joaquín Manuel (2005): “El escultor Antonio de las Peñas y León”. En: Laboratorio de Arte, 18, pp. 479-492.

Camacho Martínez, Rosario/Coloma Martín, Isidoro (2006): Guía artística de Málaga y su provincia (I). Sevilla: Fundación José Manuel Lara.

Camino Romero, Andrés (2001): Breve historia de un Cristo olvidado. Málaga: Agrupación de Cofradías de Semana Santa de Málaga.

Cánovas Vallejo, Antonio (1908): Apuntes para un diccionario de pintores malagueños del s. XIX. Madrid: Imprenta de Antonio G. Izquierdo.

García Rubio, Pablo (1994): La Iglesia Evangélica Española, iglesia protestante. 125 años de vida y testimonio. Barcelona: Departamento de publicaciones de la Iglesia Evangélica Española.

Gómez Román, Ana María (2008): “Torcuato Ruiz del Peral y el devenir de la escultura en Granada hasta mediados del s. XIX". En: Boletín del Centro de Estudios Pedro Suárez, 21, pp. 327-398.

Guillén Robles, Francisco (1874): Historia de Málaga y su provincia. Málaga: Imprenta de Rubio y Cano.

Menéndez Pelayo, Marcelino (1881): Historia de los Heterodoxos españoles. Madrid: Librería Católica de San José, tomo 3.

Moliner Prada, Antonio (2016): "En torno a la Revolución Liberal y la Iglesia española del siglo XIX”. En: Ler História, 69, pp. 31-50.

Reder Gadow, Marion (2007): "Historia de la devoción a la Virgen de los Remedios en Málaga”. En: Retana Rojano, Rafael (coord.): Historia devocional en la Málaga del s. XVIII: La Antigua Hermandad del Santo Rosario de Nuestra Señora de los Remedios de la Parroquia de los Santos Mártires. Málaga: Ayuntamiento de Málaga/Antigua Hermandad del Santo Rosario de Nuestra Señora de los Remedios, pp. 43-70. 
Romero Mensaque, Carlos José (2010): "El rosario y sus cofradías en Andalucía. Una aproximación histórica". En: Hispania Sacra, LXII, 126, pp. 621-659.

Romero Torres, José Luis (1981): "La escultura en Málaga a fines del siglo XIX". En: AA.VV.: Una sociedad a fines del siglo XIX: Málaga. Centenario MálagaPicasso. Madrid: Ministerio de Cultura.

(1993): Los barros malagueños del Museo de Unicaja de Artes Populares Mesón de la Victoria. Málaga: Unicaja.

(2007): "La Virgen de los Remedios en el contexto de la producción escultórica de Fernando Ortiz". En: Retana Rojano, Rafael (coord.): Historia devocional en la Málaga del s. XVIII. La Antigua Hermandad del Santo Rosario de Nuestra Señora de los Remedios de la Parroquia de los Santos Mártires, Málaga: Ayuntamiento de Málaga/Antigua Hermandad del Santo Rosario de Nuestra Señora de los Remedios, pp. 85-104.

(2017): Fernando Ortiz. Un escultor malagueño del siglo XVIII. Osuna: Patronato de Arte y Amigos de los Museos de Osuna.

(2019): Pedro de Mena. Granatensis malacae. Málaga: Obispado de Málaga.

Rubino, A. (1978): Dizionario degli instituti di Perfezzione. Roma: Edizione Paoline.

Sánchez López, Juan Antonio (1996): El alma de la madera. Cinco siglos de iconografía y escultura procesional en Málaga. Málaga: Hermandad de Nuestro Padre Jesús del Santo Suplicio, Santísimo Cristo de los Milagros y María Santísima de la Amargura.

(2007): "Apuntes iconográficos y artísticos sobre la imagen de Ntra. Sra. de los Remedios". En: Retana Rojano, Rafael (coord.): Historia devocional en la Málaga del s. XVIII. La Antigua Hermandad del Santo Rosario de Nuestra Señora de los Remedios de la Parroquia de los Santos Mártires, Málaga: Ayuntamiento de Málaga/Antigua Hermandad del Santo Rosario de Nuestra Señora de los Remedios, pp. 71-84.

Sierra Bernardino, Evangelina (1998): La heterodoxia protestante en la Edad Contemporánea. Antecedentes, génesis y evolución de las Asambleas de Hermanos (Galicia 1868-1931). Tesis doctoral: Universidad de Vigo.

Vilar, Juan Bautista (1994): Intolerancia y libertad en la España contemporánea. Los orígenes del protestantismo español actual. Madrid: Ediciones Istmo. 


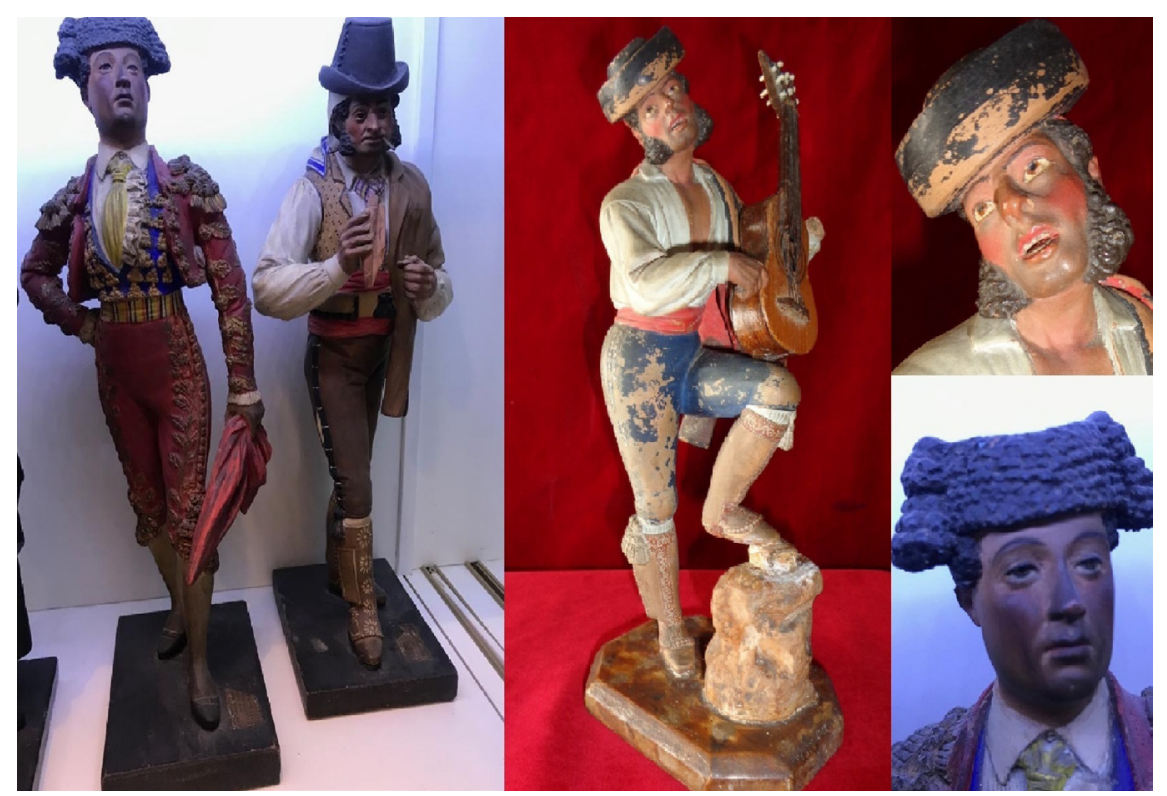

Figura 1. Antonio Marín Sánchez, Torero, Majo con navaja y Bandolero con guitarra, 1863-1868, colección particular, Málaga. Fotos: Antonio Pedraza Alba y Juan Fernández Prat.

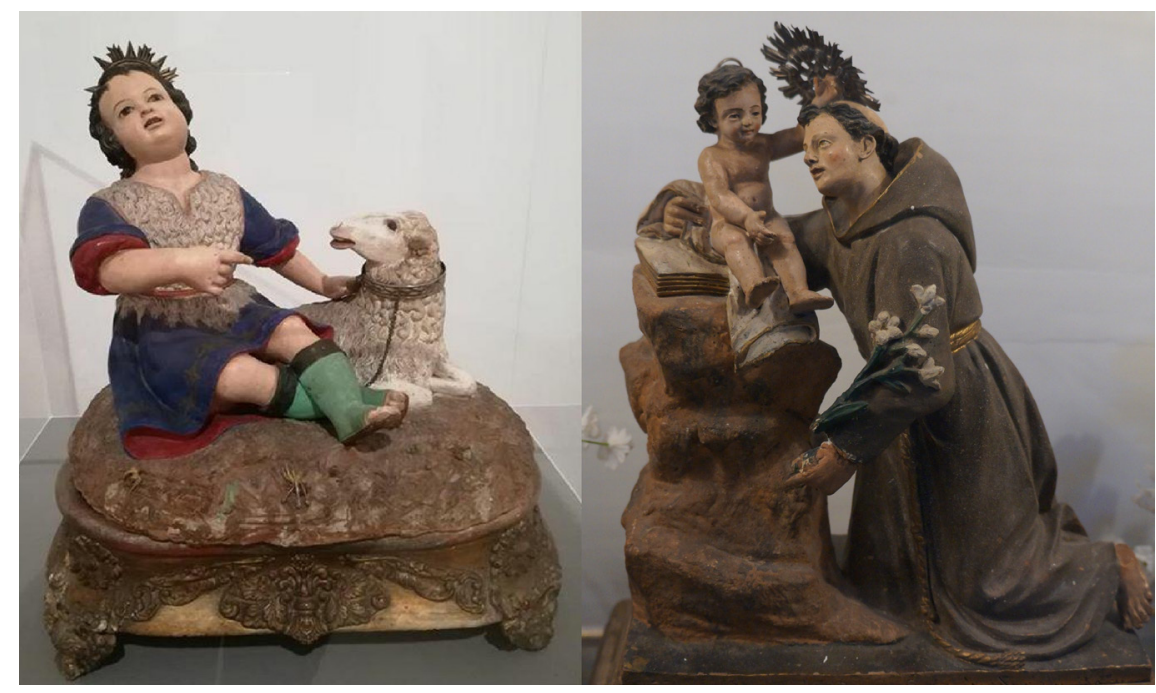

Figura 2. a) Antonio Marín Sánchez, Divino Pastor, década de 1840, Museo de Artes y Costumbres Populares, Málaga. Foto: Jesús López-Alfonso. b) Antonio Marín Sánchez, San Antonio de Padua, segunda mitad del siglo XIX, iglesia de las Mercedarias, Málaga. Foto: Francisco Jesús Flores Matute. 


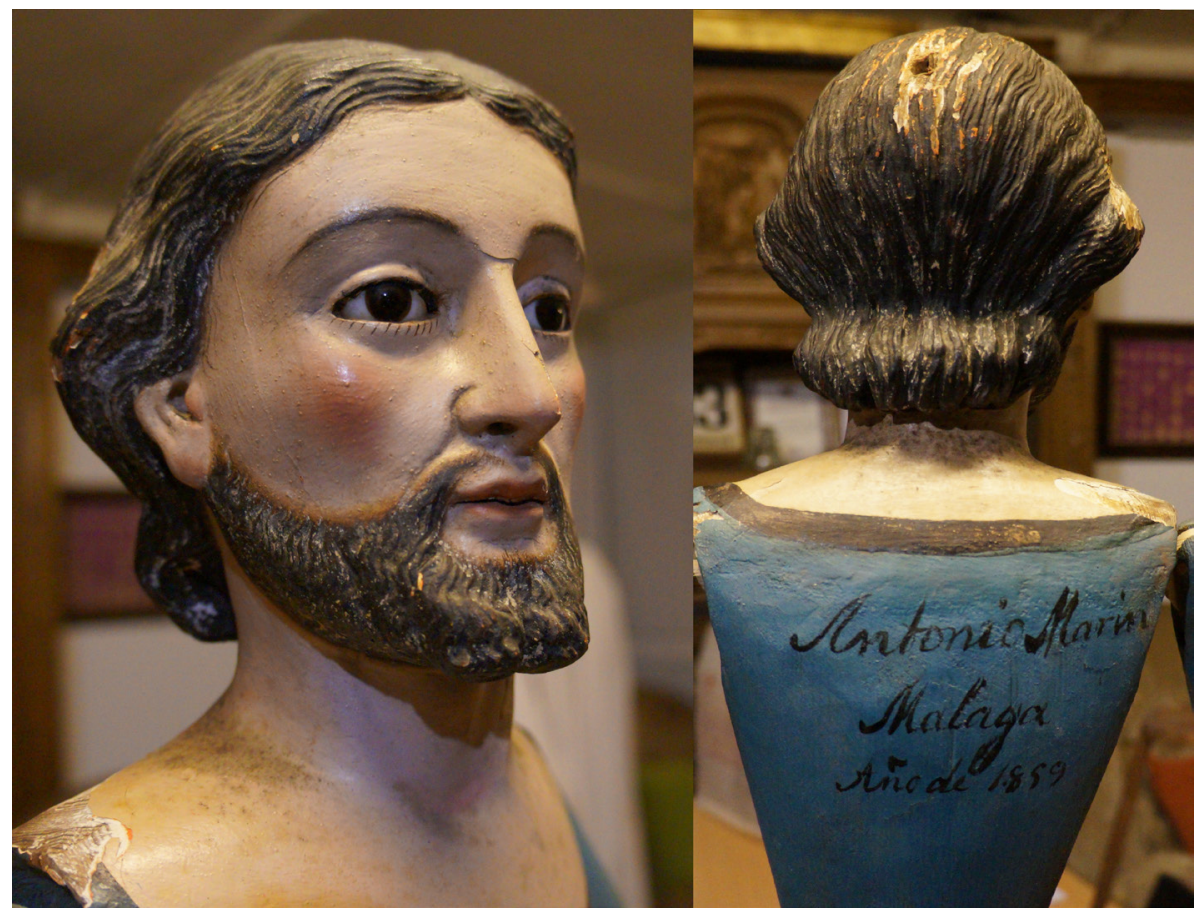

Figura 3. Antonio Marín Sánchez, San José (rostro y firma), 1859, colección particular, Málaga. Fotos: Francisco Jesús Flores Matute.

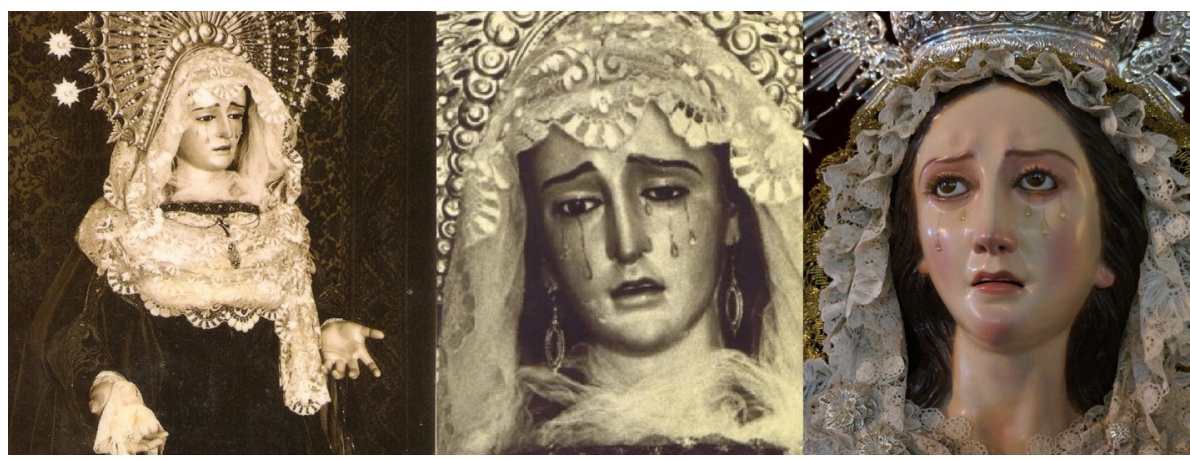

Figura 4. a) y b) Antonio Marín Sánchez, Virgen del Amor, década de 1870, parroquia de Santiago, Málaga. Foto: Archivo de la Hermandad del Rico. c) Antonio Marín Sánchez (atribución), Virgen de los Dolores y Esperanza, década de 1870, parroquia de San Vicente de Paúl, Málaga. Foto: Francisco Jesús Flores Matute. 


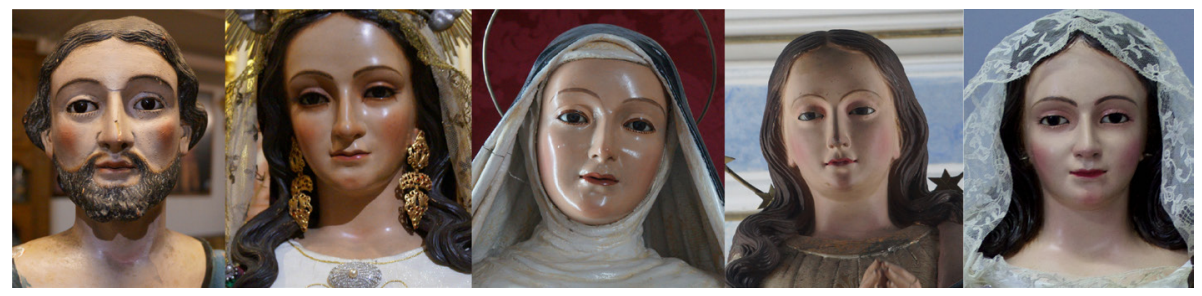

Figura 5. Antonio Marín Sánchez, Comparativa de los rostros de San José, Virgen de los Remedios (atribución), Santa Escolástica (atribución), Inmaculada Concepción (atribución) y Virgen del Rosario (atribución), segunda mitad del siglo XIX, colección particular (Málaga), parroquia de los Santos Mártires (Málaga), ermita de San Benito (Campillos,

Málaga), iglesia de las Mercedarias (Málaga) y parroquia de Nuestra Señora del Rosario (Serrato, Málaga) respectivamente. Fotos: Francisco Jesús Flores Matute y David Montilla.

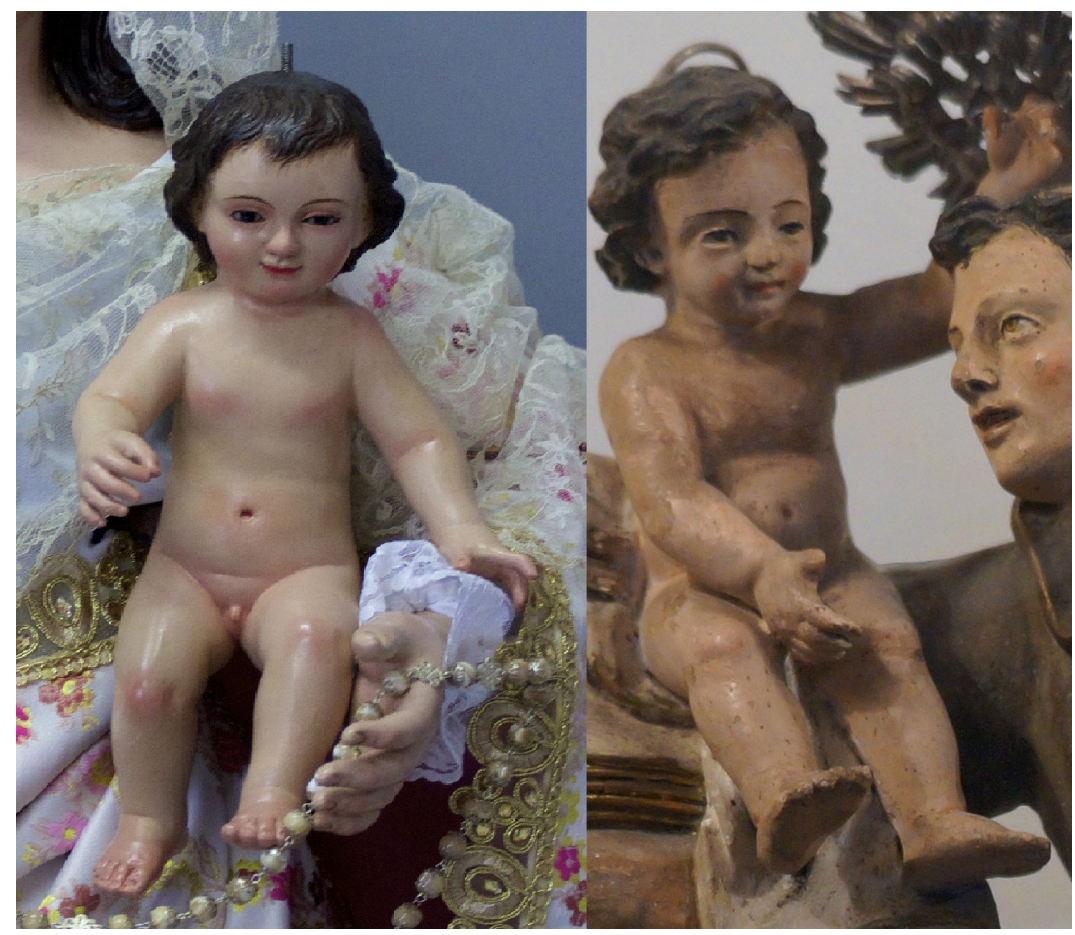

Figura 6. Antonio Marín Sánchez, Comparativa entre el Niño Jesús de la Virgen del Rosario de Serrato y el Niño Jesús del San Antonio de las Mercedarias de Málaga, siglo XIX. Fotos: David Montilla y Francisco Jesús Flores Matute. 


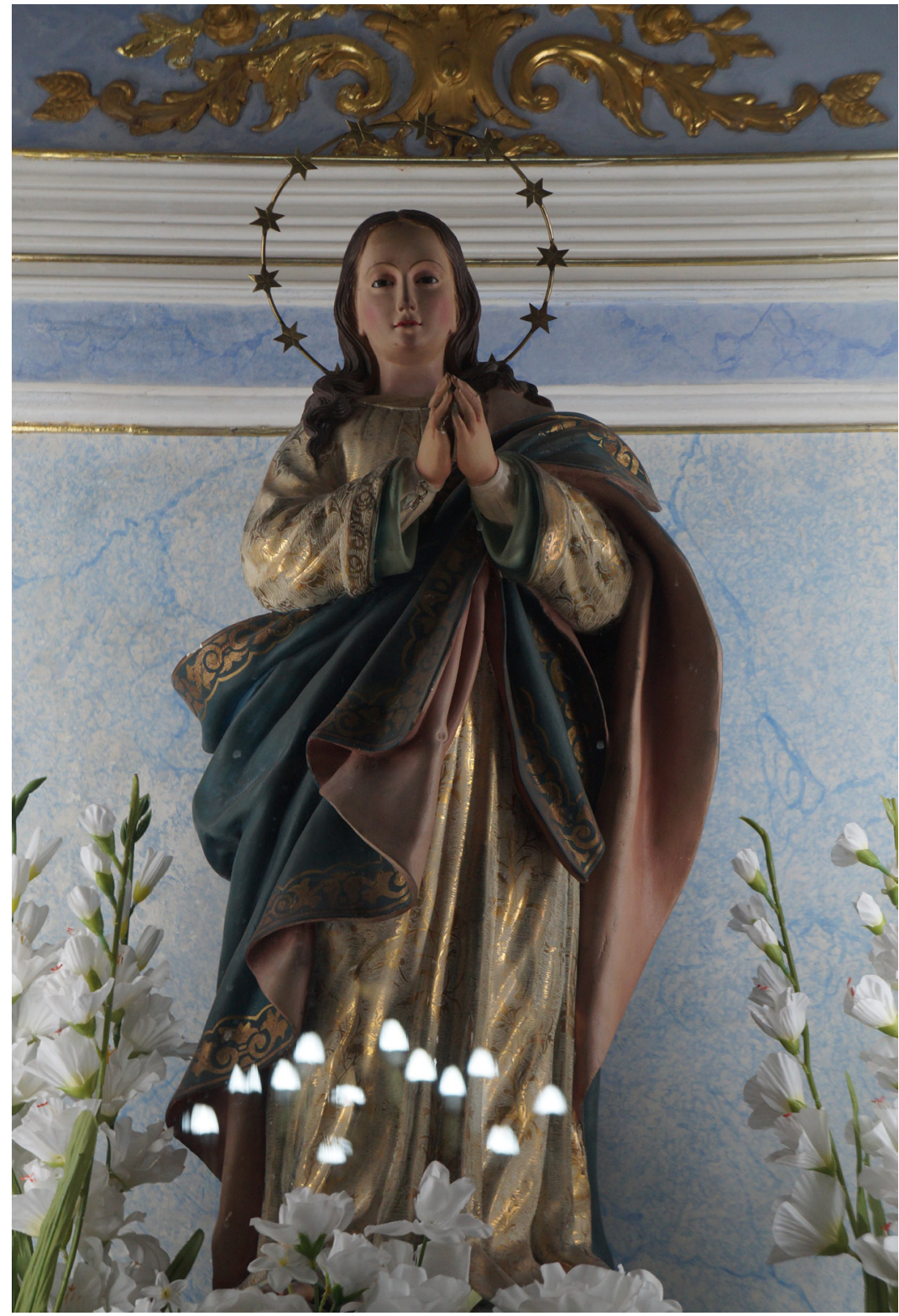

Figura 7. Antonio Marín Sánchez (atribución), Inmaculada Concepción, segunda mitad del siglo XIX, iglesia conventual de las Mercedarias de la Caridad, Málaga. Foto: Francisco Jesús Flores Matute. 


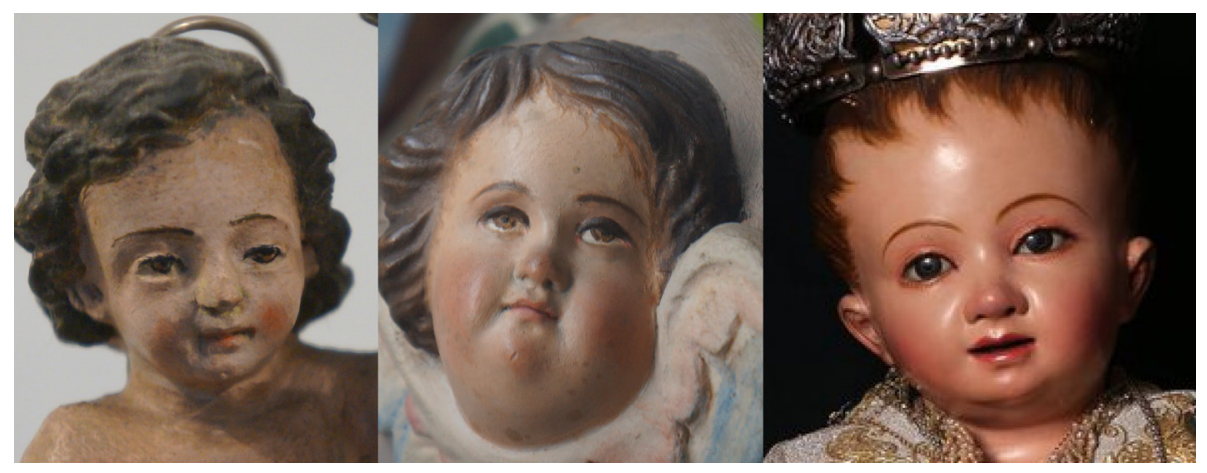

Figura 8. Antonio Marín Sánchez, Comparativa de los rostros del Niño Jesús del San Antonio de Padua, Querubín de la nube de la Inmaculada (atribución) y Niño Jesús de la Virgen de los Remedios (atribución), segunda mitad del siglo XIX, iglesia conventual de las Mercedarias de la Caridad y parroquia de los Santos Mártires, Málaga. Fotos: Francisco Jesús Flores Matute. 